\title{
The Normative Influence of the UN Guiding Principles on the Kampala Convention in the Protection of Internally Displaced Persons in Africa
}

\author{
Francis M Deng* \\ Former Representative of the UN Secretary-General; Ambassador, South Sudan \\ francismdeng@gmail.com
}

\section{Romola Adeola**}

University of Pretoria, South Africa

romola.adeola@gmail.com

\begin{abstract}
Over the last several decades, states have demonstrated significant political commitment towards advancing protection and assistance for internally displaced persons. A notable form in which this commitment has been reflected is in the emergence of normative standards, with the UN Guiding Principles on Internal Displacement (UNGP) as the guiding text. The fact that the UNGP framework has found expression in the landscape on internal displacement is evidenced at various levels of governance. Within the African context, the African Union Convention for the Protection and Assistance of Internally Displaced Persons in Africa (Kampala Convention) draws on pertinent normative frameworks, with the UNGP as the leading framework. While this point is often made in general terms, this article focuses on the extent to which the norm on internal displacement has diffused and expanded within the African context.
\end{abstract}

\section{Keywords}

Internal displacement, internally displaced persons, law and policy, Guiding Principles, Kampala Convention, Africa

\footnotetext{
* Representative of the UN Secretary-General on Internally Displaced Persons (1992-2004); ambassador, South Sudan.

** Coordinator, Global Engagement Network on Internal Displacement in Africa; fellow, Centre for Human Rights, Faculty of Law, University of Pretoria, South Africa.
} 


\section{INTRODUCTION}

Soft laws are not categorically recognized as sources of international law, ${ }^{1}$ yet they are increasingly gaining momentum as the culmination of collective action on pertinent global issues for which sustainable solutions are required. ${ }^{2}$ Whether it be on the issue of climate change or migration, what is evident is that soft laws are supporting hard law formations. In the context of internal displacement, for instance, the emergence of the UN Guiding Principles on Internal Displacement (UNGP) ${ }^{3}$ evidences this fact.

Over the last two decades, the impact of the UNGP has been evident at various levels of governance. Both in law and policy formations, ${ }^{4}$ the UNGP have etched a place on the internal displacement landscape. It is now widely accepted that the UNGP are the basis on which actions on internal displacement need to be predicated. Indeed, some scholars have pointed to the fact that this soft law is crystalizing into customary international law given the level of support it enjoys in both opinio juris [acceptance of a practice as sufficient to create legal obligations] and state practice. ${ }^{5}$

The extensive scholarly work on the UNGP attests to the importance of this framework as the primary text on internal displacement. ${ }^{6}$ The great body of

1 T Grnchalla-Wesierski “A framework for understanding 'soft law”" (1984) McGill Law Journal 29 at 44; CM Chinkin "The challenge of soft law: Development and change in international law" (1989) 38 International and Comparative Law Quarterly 850; P-M Dupuy "Soft law and the international law of the environment" (1991) 12/2 Michigan Journal of International Law 420; AE Boyle "Some reflections on the relationship of treaties and soft law" (1999) 48/4 International and Comparative Law Quarterly 901; KW Abbott and D Snidal "Hard and soft law in international governance" (2000) 54/3 International Organization 421; AT Guzman and TL Meyer "International soft law" (2010) 2 Journal of Legal Analysis 171; GC Shaffer and MA Pollack "Hard vs soft law: Alternatives, complements, and antagonists in international governance" (2010) 94 Minnesota Law Review 706; P Orchard "Protection of internally displaced persons: Soft law as a norm-generating mechanism" (2010) 36 Review of International Studies 281; IA Olsson "Four competing approaches to international soft law" (2013) 58 Scandinavian Study in Law 177; U Baxi "The softening of hard law and the hardening of soft law: An extended synopsis" in DD Bradlow and DB Hunter (eds) Advocating Social Change Through International Law: Exploring the Choice Between the Hard and Soft International Law (2019, Brill Nijhoff) 16.

2 See for instance: Paris Agreement (2015); Global Compact on Safe, Orderly and Regular Migration (2018).

3 UN Commission on Human Rights, addendum "Guiding Principles on Internal Displacement" (report of the representative of the Secretary-General, Mr Francis M Deng, submitted pursuant to UN Commission on Human Rights res 1997/39), UN doc E/CN.4/1998/53/Add.2 (11 February 1998).

4 See Peru: Law No 28223 on Internal Displacement (2004); Uganda: National Policy for Internally Displaced Persons (2004); Nepal: National Policies on Internally Displaced Persons, 2063 (2007).

5 See for instance, DJ Cantor Returns of Internally Displaced Persons During Armed Conflict (2018, Brill Nijhoff) at 113.

6 PL Schmidt "The process and prospects for the UN Guiding Principles on Internal Displacement to become customary international law: A preliminary assessment" (2004) 35/3 Georgetown Journal of International Law 483; S Bagshaw Developing a 
scholarship has posited the extensive influence of the UNGP in various contexts, from Columbia to Afghanistan. ${ }^{7}$ Increasingly, there is growing acknowledgement that compliance with the UNGP is shaping political rhetoric on internal displacement. A subject that previously fell within the discretionary ambit of the state (whether or not it chose to act) is now becoming a global collective issue. With the great concern from the international community on the welfare of populations within the borders of states, internal displacement has gained traction within global and regional systems of governance, and the influence of the UNGP in this regard is telling. Besides shaping political commitment, the UNGP have found expression in law and policy formations. This article reflects on the influence of the UNGP in the development of the 2009 African Union (AU) Convention for the Protection and Assistance of Internally Displaced Persons in Africa (Kampala Convention).

In advancing the discussion, this article is divided into three parts. The first examines the UNGP as the leading global text on internal displacement. Given the existence of a rich body of work on the formation of the UNGP, the article provides a concise reflection on the relevance of the UNGP as a global text on internal displacement. The second part examines the synergies between the UNGP, the Kampala Convention and expansions of the later norm. The third part examines areas around which legal protection for internally displaced persons (IDPs) needs to be strengthened, leveraging on law on internal displacement as reflected in the UNGP and Kampala Convention.

\section{THE GUIDING PRINCIPLES AS THE GLOBAL INTERNALLY DISPLACED PERSONS TEXT}

While the process that led to the formation of the UNGP emerged in the 1990s, realization of the gap in global governance on internal displacement began in

contd

Normative Framework for the Protection of Internally Displaced Persons (2005, Transactional Publishers); C Phuong The International Protection of Internally Displaced Persons (2005, Cambridge University Press); W Kälin "The Guiding Principles on Internal Displacement as [sic] international minimum standard and protection tool" (2005) 24/3 Refugee Survey Quarterly 27; TG Weiss and DA Korn Internal Displacement: Conceptualization and Its Consequences (2006, Routledge); R Cohen and F Deng "The genesis and challenges of the Guiding Principles on Internal Displacement" (2008) Forced Migration Review 4; M Mandal The Rise of Revolution: Internal Displacement in Contemporary Nepal (2018, Routledge); A Bilak and A Shai "Internal displacement beyond 2018: The road ahead” (2018) 59 Forced Migration Review 49; G Cardona-Fox Exile Within Borders: A Global Look at Commitment to the International Regime to Protect Internally Displaced Persons (2019, Brill); P Orchard Protecting the Internally Displaced: Rhetoric and Reality (2019, Routledge).

7 RK Goldman "Internal displacement, the Guiding Principles on Internal Displacement, the principles' normative status, and the need for their effective domestic implementation in Colombia" (2009) 2 Anuario Colombiano de Derecho Internacional 59; N Majidi and D Tyler "Domesticating the Guiding Principles in Afghanistan" (2018) 59 Forced Migration Review 65. 
the 1980s with an International Conference in Oslo on the Plight of Refugees, Returnees and Displaced Persons in Southern Africa. ${ }^{8}$ This conference considered the importance of addressing the gap in global governance on issues relating to IDPs. The UN Secretary-General (UNSG) was requested to conduct studies on relief for IDPs. ${ }^{9}$ Following a series of decisions and continued advocacy, in the early 1990s, the UN Commission on Human Rights (UN Commission) requested the UNSG to appoint a specific representative on IDP issues with the objective of studying existing international standards on internal displacement. ${ }^{10}$ So dire was the situation experienced by IDPs, that a specific normative framework needed to be developed in response to their plight. Unlike refugees, IDPs did not cross an international border. The fact that they remained within the borders of the state of displacement meant that their protection could not fall within the sphere of the UN Convention Relating to the Status of Refugees (1951), as a significant condition that must be met to trigger the application of the UN convention is the notion of alienage (the state or condition of being outside the country of origin). ${ }^{11}$ There were other relevant corpuses, particularly in international human rights and humanitarian law. However, there was also a consensus among those who desired the implementation of existing norms and others who requested that the gaps in existing frameworks be covered; this was "the need to strengthen protection for the displaced". ${ }^{12}$ In the end, what was proposed was an initial statement of principles ${ }^{13}$ that, although not legally binding, would focus international attention, raise the level of awareness and stimulate practical measures to alleviate the crisis.

While this was to establish the premise for a later "legally binding document", ${ }^{14}$ it ensured comprehensive protection for IDPs, leveraging on the

8 UN General Assembly "International Conference on the Plight of Refugees, Returnees and Displaced Persons" (annex report to the International Conference on the Plight of Refugees, Returnees and Displaced in Southern Africa), UN doc A/43/717 (19 October 1988).

9 Para 21 of the plan of action agreed at the conference provides: "In view of the absence of a United Nations operational body specifically charged to deal with the problems of and assistance to internally displaced persons, the Secretary-General of the United Nations is requested to undertake studies and consultations in order to ensure timely implementation and overall co-ordination of relief programmes for these people." See Oslo Declaration and Plan of Action, available at: <https://www.refworld.org/do cid/3ae68f3d8.html> (last accessed 28 December 2020).

10 UN Commission "Internally displaced persons", UN doc E/CN.4/RES/1992/73 (5 March 1992).

11 See GS Goodwin-Gill and J McAdam The Refugee in International Law (2007, Oxford University Press); JC Hathaway and M Foster The Law of Refugee Status (2014, Cambridge University Press).

12 See UN Commission "Comprehensive study on the human rights issues related to internally displaced persons", prepared by FM Deng, representative of the UNSG, UN doc E/CN.4/1993/35 (21 January 1993), para 280.

13 Id, para 283.

14 Ibid. 
pertinent guidance in the international legal regime of relevance and significance to IDP issues. Since members of the UN Commission resisted the development of a "legal framework", a "normative framework" was also opposed as another formulation of a "legal framework". The UNSG's representative was requested to develop an "appropriate" framework, opening doors for developing "soft law" on the issue. Eventually, the UNGP were developed and presented to the UN Commission in 1998 after extensive discussions with various stakeholders and studies on the issue.

Many international legal scholars and representatives of pertinent human rights and humanitarian agencies were involved in developing the UNGP under the guidance of the UNSG's representative. The process began with a joint meeting of law students and professors from Yale and Harvard Universities and then focused on several key individuals. Although not a lawyer herself, Roberta Cohen (who, with the UNSG's representative, co-chaired the Brookings Project on Internal Displacement that supported the mandate) was instrumental in jumpstarting the development of the UNGP. A team of leading scholars, chaired by Walter Kälin of Bern University, and with Robert Goldman of American University and Manfred Nowak of the University of Vienna as members, finalized the UNGP. Kälin succeeded Deng as the UNSG's representative and was in turn succeeded by Chaloka Beyani, who later played a leading role in the development of the Kampala Convention.

Over the last two decades, the UNGP have enjoyed significant recognition as the global text on internal displacement. The normative value of the UNGP has been visible in a plethora of norms at national level in various regions of the world. Countries have engaged in IDP protection leveraging on these norms. In Columbia, for instance, the Constitutional Court drew heavily on the UNGP in articulating what standards are required in the protection of IDPs within the national context. ${ }^{15}$ Countries such as Kenya and El Salvador have developed hard law with the UNGP as a normative text. ${ }^{16}$ There have also been policy developments on internal displacement in countries such as Yemen and Vanuatu based on the UNGP. ${ }^{17}$ At the level of the UN General Assembly (GA), the UNGP have gained recognition as "an important international framework for the protection of internally displaced persons". ${ }^{18}$ In

15 Columbia Constitutional Court, decision T-025 of 2004.

16 See Kenya Prevention, Protection and Assistance to Internally Displaced Persons and Affected Communities Act (2012); "New El Salvador law, a victory for forced displacement victims: UN refugee agency" (10 January 2020) UN News. See generally I Nicolau and A Pagot "Laws and policies on internal displacement: Global adoption and gaps" (2018) 59 Forced Migration Review 9.

17 National Policy for Addressing International Displacement in the Republic of Yemen (2013); Vanuatu National Policy on Climate Change and Disaster-Induced Displacement (2018).

18 World Summit outcome, adopted by the GA, res 60/1, UN doc A/RES/60/1 (24 October 2005), para 132. 
advocacy, research and operational programmes on internal displacement, the significance of the UNGP resonates further. While stakeholders in various contexts have found the UNGP useful in developing sustainable solutions on internal displacement, this article examines their normative synergies with the Kampala Convention.

\section{FROM GLOBAL TO REGIONAL: SYNERGIES AND EXPANSIONS}

Over the last two decades, the influence of the UNGP on the African continent has emerged through the establishment of normative standards. In the Great Lakes Region, this is visible with the regional protocol that specifically incorporates the UNGP and mandates states to "adopt and implement the Guiding Principles as a regional framework for providing protection and assistance to internally displaced persons in the Great Lakes Region". ${ }^{19}$ Kenya's IDP law is regarded as a laudable beacon of this framework. ${ }^{20}$ Uganda was the country that led the way in using the UNGP to adopt a national framework on internal displacement, which is why it also chaperoned the development of the Kampala Convention. ${ }^{21}$ Another pertinent way in which the UNGP have been reflected in the national context is through an executive decision, explicitly incorporating the UNGP in the national context. An example of this is in Liberia with the Instrument of Adoption of the UNGP, the operative part of which reads: "[t]he National Transitional Government of Liberia does hereby adopt in Perry Town, Liberia, on 8 November 2004, the Guiding Principles on Internal Displacement to serve as a source of ongoing guidance and reference for the protection, dignity and rights of internally displaced persons, who themselves are the People of Liberia and are worthy of the rights and freedoms thereof". ${ }^{22}$

While drawing on the wide array of regional and international standards, the Kampala Convention recognizes the UNGP "as an important international framework for the protection of internally displaced persons". ${ }^{23}$ During the drafting of the Kampala Convention, stakeholders felt that the provisions of the UNGP should guide the content of the regional text. At a meeting of legal experts from AU member states in 2008, it was recommended that there was a need to make reference to the UNGP "while keeping a certain level of balance as far as the African substance is concerned". ${ }^{24}$ Beyani observes that, while the Kampala Convention modernizes the IDP protection regime, it

19 Protocol on the Protection and Assistance to Internally Displaced Persons, adopted by the International Conference on the Great Lakes (2006), art 6(1).

20 Kenya Prevention, Protection and Assistance to Internally Displaced Persons and Affected Communities Act.

21 Uganda National Policy for Internally Displaced Persons (2004).

22 Liberia Instrument of Adoption of Guiding Principles on Internally Displaced Persons (8 November 2004).

23 Kampala Convention, preamble.

24 "Report of the proceedings of the second meeting of AU member states legal experts on 
"still reinforces the Guiding Principles pioneering a combined framework of international human rights law, international humanitarian law, and the analogical application of international refugee law". ${ }^{25}$

One of the areas in which the Kampala Convention heavily mirrors the UNGP is in its emphasis on the need for states to ensure conformity with international law in preventing "conditions that might lead to the arbitrary displacement of persons". ${ }^{26}$ Within the African regional context, this further expands to regional normative frameworks, including human rights texts on specific groups, such as women, children, persons with disabilities and older persons. ${ }^{27}$ Specific provisions of international law, particularly in relation to human rights and humanitarian law, are detailed in both instruments, although the UNGP are generally more detailed with respect to human rights. ${ }^{28}$ While both instruments adopt the same description of IDPs, an expansion of the Kampala Convention is in its specific definition of internal displacement as "the involuntary or forced movement, evacuation or relocation of persons or groups of persons within internationally recognized state borders". ${ }^{29}$ Building on the UNGP, the Kampala Convention captures core elements in describing internal displacement without much emphasis on root causes, given that the listed root causes in the IDP description are not, in themselves, exhaustive, as also reflected in the UNGP. Recognition of other issues in the text of both instruments, such as development-induced displacement, is instructive.

Moreover, the Kampala Convention draws on the UNGP in its provision of a right not to be arbitrarily displaced, which is a cardinal doctrine of internal displacement. ${ }^{30}$ Encased in this right is a rich panoply of legal norms, drawing on existing standards around which the protection and assistance of IDPs find expression. In particular, this cardinal doctrine is reaffirmed in a plethora of norms at various levels of governance. What is telling about this cardinal doctrine is that it affords a premise on which the modalities for the furtherance of IDP protection and assistance may be constructed. Doctrinally, the right not to

contd the draft AU Convention for the Protection and Assistance of Internally Displaced Person in Africa" (2-6 June 2008) at 10 (copy on file with the authors).

25 C Beyani "A view from inside the kitchen of the Kampala Convention: The modernisation of the international legal regime for the protection of internally displaced persons" (LSE Legal Studies working paper no 17/2020) at 8, available at: <https://papers.ssrn.com/sol 3/papers.cfm?abstract_id=3736788> (last accessed 26 January 2021).

26 UNGP, principle 5; Kampala Convention, art 4(1).

27 African Charter on the Rights and Welfare of the Child (1990); Protocol to the African Charter on Human and Peoples' Rights on the Rights of Women in Africa (2003); Protocol to the African Charter on Human and Peoples' Rights on the Rights of Older Persons in Africa (2016); Protocol to the African Charter on Human and Peoples' Rights on the Rights of Persons with Disabilities in Africa (2018).

28 See UNGP, principles 10-23.

29 Kampala Convention, art 1(1).

30 UNGP, principle 6(1); Kampala Convention, art 4(4). 
be arbitrarily displaced encompasses two significant dimensions: displacement must conform to international law, including human rights and humanitarian law; and due process of law must be followed.

The Kampala Convention further draws on the UNGP in recognizing national authorities as primary duty bearers and, as such, reinforcing the notion of state responsibility. ${ }^{31}$ This recognition derives from a global recognition of sovereignty as responsibility and, as such, states are to protect everyone within their national territories from arbitrary displacement. The idea of "sovereignty as responsibility" was developed at the Brookings Africa Program led by the lead author of this article (Francis Deng). As Deng was the UNSG's representative on IDPs, this principle guided dialogue with governments in discharging their mandate. It also provided the basis for the development of sovereignty as responsibility within the UNGP, which is widely recognized as the foundation of the responsibility to protect. The two rest on the three pillars involving: state responsibility; international assistance to the needy state; and international intervention in case of manifest failure of a state to protect its population. However, while sovereignty as responsibility is rightly understood as prioritizing state responsibility, responsibility to protect is seen as advocating international intervention, which is why it is controversial and being resisted by some countries.

In furthering this primary duty, states are to "respect and ensure respect for their obligations under international law, including human rights and humanitarian law, in all circumstances, so as to prevent and avoid conditions that might lead to displacement of persons". ${ }^{32}$ Implicitly, this would also require states to ensure accountability of non-state actors whose actions may result in internal displacement. The Kampala Convention is emphatic on this point and significantly articulates the need for states to ensure accountability of these actors "including multinational companies and private military or security companies". ${ }^{33}$ Observing the regional landscape on internal displacement in Africa and the role of actors, other than states, reinforces the pertinence of these provisions and the need to pay particular attention to the activities of non-state actors in the context of internal displacement. This is buttressed by the fact that situations of development-induced displacement, for instance, or armed conflict, are increasingly being shaped by the actions of non-state actors on the continent and, indeed, in other parts of the world. ${ }^{34}$ For their part, the UNGP reinforce the fact that the "Principles shall be observed by all authorities, groups and persons irrespective of their legal status". ${ }^{35}$ However, the observance of these principles "shall not affect

31 UNGP, principle 3; Kampala Convention, art 5(1).

32 Kampala Convention, art 4(1).

$33 \mathrm{Id}$, art 3(1)(h).

34 See R Adeola Development-Induced Displacement and Human Rights in Africa: The Kampala Convention (2021, Routledge).

UNGP, principle 2 . 
the legal status of any authorities, groups or persons involved". ${ }^{36}$ Consequently, observance of these principles cannot be read to imply the legitimization, for instance, of armed groups. The Kampala Convention is emphatic on this, in stating that it "shall not be construed as affording legal status or legitimizing or recognizing armed groups". ${ }^{37}$ During the drafting of the Kampala Convention, the inclusion of armed groups was "contested" up until the $2009 \mathrm{AU}$ summit. Beyani notes that, "[t]heir inclusion in the Convention at the insistence of displacement affected States marked the hall mark of the Convention as a modernising treaty that combines the responsibilities of States, and those of armed groups in the field of internal displacement". ${ }^{38}$

Notably, both instruments emphasize the right of IDPs to seek asylum in another country. The UNGP express this point in emphasizing that IDPs have the right to "seek safety in another part of the country", "leave their country", "seek asylum in another country" as well as protection from forcible return. ${ }^{39}$ The Kampala Convention also makes this point with explicit reference to global and regional refugee frameworks, specifically the 1969 OAU Convention Governing the Specific Aspects of Refugee Problems in Africa (OAU Refugee Convention), which expands the grounds for refugee status. ${ }^{40}$ The importance of this is that it affords an expanded space for IDPs to be protected as refugees in another country, for instance in situations of generalized violence or where displacement is due to natural disasters, including climate change. Although the notion of "climate refugees" has not been concretely cemented in state practice, there is an increasing momentum at the regional level that the expanded refugee definition may also extend to cross-border climate displacement, ${ }^{41}$ however, much of the question rests on an interpretation of the notion of "events seriously disturbing public order". ${ }^{42}$ While an

36 Id, principle 2(1).

37 Kampala Convention, art 15(2).

38 Beyani "A view from inside", above at note 25 at 11.

39 UNGP, principle 15.

40 Kampala Convention, art 20(1).

41 For instance, one of the outcomes of the Roundtable on Addressing Root Causes of Forced Displacement and Achieving Durable Solutions in Africa (held in Addis Ababa, 2019, as part of the AU Project 2019 on Refugees, Returnees and Internally Displaced Persons) was that the "regional definition in the 1969 OAU Convention may allow decision-makers to recognise refugee status in the context of climate change". See AU "Summary conclusions: Roundtable on Addressing Root Causes and Achieving Durable Solutions in Africa" (Addis Ababa, Ethiopia, 9 February 2019) at 6 (copy on file with the authors).

42 The expanded definition contained in article 1(2) of the OAU Refugee Convention provides that a refugee is "every person who, owing to external aggression, occupation, foreign domination or events seriously disturbing public order in either part or the whole of his country of origin or nationality, is compelled to leave his place of habitual residence in order to seek refuge in another place outside his country of origin or nationality" (emphasis added). See generally MR Rwelamira "Two decades of the 1969 OAU Convention Governing the Specific Aspects of the Refugee Problem in Africa" (1989) 
interpretation is yet emerging, the fact that the Kampala Convention reinforces the notion of climate IDPs points to this trajectory.

The Kampala Convention further draws on the UNGP through its emphasis on the primary responsibility of states in providing humanitarian assistance, further recognizing that international humanitarian organizations may offer "their services" 43 in assistance. However, the UNGP emphasize that consent "shall not be arbitrarily withheld". ${ }^{44}$ Although the Kampala Convention does not include this provision, it emphasizes cooperation and the need for states to respect the mandate of "the African Union and the United Nations, as well as the roles of international humanitarian organizations in providing protection and assistance to internally displaced persons, in accordance with international law". ${ }^{45}$ However, both instruments reinforce the right of IDPs in seeking humanitarian assistance: a right with a corollary duty for which legitimate demands may emerge under the Kampala Convention. While both instruments recognize that states shall not persecute or punish IDPs for asserting this right, the Kampala Convention further prohibits the prosecution of IDPs. ${ }^{46}$

Another pertinent area of synergy is in relation to durable solutions, encompassing return, integration and resettlement. While both instruments reinforce IDP participation in the processes of seeking durable solutions, the Kampala Convention further emphasizes the "free and informed choice" of IDPs. ${ }^{47}$ Both instruments recognize the need to safeguard IDP property. While the UNGP emphasize the need for authorities to assist IDPs who are dispossessed of their property, the Kampala Convention further mandate states to "establish appropriate mechanisms providing for simplified procedures where necessary, for resolving disputes relating to the property of internally displaced persons". ${ }^{48}$ As IDPs may lose housing, land and property, this

contd

1/4 International Journal of Refugee Law 557; G Okoth-Obbo "Thirty years on: A legal review of the 1969 OAU Refugee Convention Governing the Specific Aspects of Refugee Problems in Africa” (2001) 20/1 Refugee Survey Quarterly 79 at 109; MB Rankin "Extending the limits or narrowing the scope? Deconstructing the OAU refugee definition thirty years on" (UN High Commission for Refugees working paper no 113, April 2005); A Edwards "Refugee status determination in Africa" (2006) 14 African Journal of International and Comparative Law 204; M Sharpe "The 1969 African Refugee Convention: Innovations, misconceptions, and omissions' (2012) 58/1 McGill Law Journal 95 at 113; T Schreier "The expanded refugee definition" in $\mathrm{F}$ Khan and $\mathrm{T}$ Schreier (eds) Refugee Law in South Africa (2014, Juta) 74 at 78; T Wood "Expanding protection in Africa? Case studies of the implementation of the 1969 African Refugee Convention's expanded refugee definition" (2014) 26/4 International Journal of Refugee Law 555; C D'Orsi Asylum-Seeker and Refugee Protection in Sub-Saharan Africa: The Peregrination of a Persecuted Human Being in Search of a Safe Haven (2016, Routledge) at 63.

43 Kampala Convention, art 5(6).

44 UNGP, principle 25(2).

45 Kampala Convention, art 5(3).

46 Id, art 5(9); UNGP, principle 3(2).

47 Kampala Convention, art 11(2).

48 Id, art 11(4). 
provision is important in achieving durable solutions. ${ }^{49}$ Both instruments emphasize the provision of compensation, although the Kampala Convention goes further, requiring the establishment of "an effective legal framework to provide just and fair compensation and other forms of reparations, where appropriate, to internally displaced persons for damages incurred as a result of displacement". ${ }^{50}$

The Kampala Convention further establishes a system for monitoring compliance, drawing on existing regional institutions. In this way, the Kampala Convention builds in existing regional reporting systems to the African Commission on Human and Peoples' Rights and the African Peer Review Mechanism. Moreover, the Kampala Convention creates a Conference of State Parties "to monitor and review the implementation" of the framework. ${ }^{51}$ Over the last decade, this conference has been formally established, creating a forum for discussion of the implementation of the instrument among state parties. Through this conference, states are able to adopt collective action on IDP issues, as evidenced with the adoption of a regional plan of action for furthering the Kampala Convention. ${ }^{52}$

While these instruments have significantly shaped the narrative on internal displacement in Africa and, indeed, have contributed to the rhetoric on protecting and assisting IDPs, it is pertinent to examine some areas in which further expansion of these norms is required. The next section considers three pertinent areas around which significant knowledge formation is required in shaping the future of legal protection on internal displacement in Africa.

\section{STRENGTHENING PROTECTION}

Strengthening legal protection for IDPs in Africa from a normative perspective will require a significant response in three pertinent areas: developing contexts, existing root causes and future concerns.

The reality that there are developing contexts for which urgent responses are required resonates with the reality of issues such as epidemics and pandemics. Over the last few decades, Ebola and, recently, COVID-19 have demonstrated the imperative for urgent solutions. ${ }^{53}$ The main argument here is that

49 See generally, Inter-Agency Standing Committee IASC Framework on Durable Solutions for Internally Displaced Persons (2010) at 35-37.

50 Kampala Convention, art 12(2) (emphasis added).

51 Id, art 14(1).

52 Harare Plan of Action for the Implementation of the Kampala Convention (2017-2022) (2017, Conference of State Parties) (copy on file with the authors).

53 See "Spiralling violence puts millions at risk in Ebola-hit eastern DRC" (24 August 2018) UN Refugee Agency; "New spike in displacement in eastern DRC further complicates Ebola responses, requires urgent relocation and response" (5 July 2019, International Organization for Migration); "Recommendations on internal displacement in Africa" (submission to the UNSG's High-Level Panel on Internal Displacement: Global Engagement Network on Internal Displacement in sub-Saharan Africa Research 
IDPs are specifically vulnerable to such situations and guidance should be provided on protecting IDPs in this context based on normative frameworks. Both the UNGP and Kampala Convention are emphatic on special measures. Principle 19(3) of the UNGP provides: "[s]pecial attention should be given to the prevention of contagious infectious diseases, including AIDS, among internally displaced persons". The Kampala Convention further requires states to provide "special protection for and assistance to internally displaced persons with special needs, including ... persons ... with communicable diseases". ${ }^{44}$ However, special attention or protection within the context of these provisions and in relation to these emerging issues is not entirely evident. Expanding on the content of these provisions in the protection of IDPs is imperative in order to adapt the norms to these emerging realities and ensure normative clarity on what states are required to do to ensure that special protection exists for IDPs in these contexts.

Moreover, there is also a need to pay attention to the existing root causes of internal displacement for which normative clarity is required, including the issue of generalized violence in both instruments, ${ }^{55}$ and climate change and harmful practices under the Kampala Convention. ${ }^{56}$ There is an emerging body of work around the reality of generalized violence as a driver of internal displacement. ${ }^{57}$ While this is also an existing root cause of internal displacement in Africa, significant knowledge on this subject area is yet to emerge. The Kampala Convention also recognized the issues of climate change and harmful practices as root causes of internal displacement, but there is limited knowledge of their prevalence and the legal protection of IDPs. Understanding the dimensions in which these root causes intersect with internal displacement and how protection should be advanced is imperative in order to strengthen legal protection for IDPs and respond effectively to the need for lasting solutions to protect and assist IDPs.

contd

Network, as part of the Interdisciplinary Network on Displacement, Conflict and Protection Project, 4 May 2020).

54 Kampala Convention, art 9(2)(c).

55 UNGP, para 2; Kampala Convention, arts 1(k) and 4(4)(d).

56 Kampala Convention, arts 4(4)(e) (harmful practices) and 5(4) (climate change).

57 See DJ Cantor "The new wave: Forced displacement caused by organized crime in Central America and Mexico" (2014) 33/3 Refugee Survey Quarterly 34; TJ Simon "Gang-based violence and internal displacement in El Salvador: Identifying trends in state response, human rights violations, and possibilities for asylum" (policy analysis exercise, Harvard University JF Kennedy School of Government, 29 March 2016); Kids in Need of Defense "Neither security nor justice: Sexual and gender-based violence and gang violence in El Salvador, Honduras, and Guatemala" (2017) at 13, available at: <https:// supportkind.org/wp-content/uploads/2017/05/Neither-Security-nor-Justice_SGBV-GangReport-FINAL.pdf> (last accessed 28 December 2020); DJ Cantor and M Plewa "Forced displacement and violent crime: A humanitarian crisis in Central America?" (2017) 69 Humanitarian Exchange 12. 
Moreover, a third dimension to strengthening protection is the need to focus on future concerns of internal displacement. Of importance is the issue of technology and the ways in which technology may be linked with other causes of internal displacement. Arguably, technology is double-edged in that it has potential benefits, particularly in the provision of humanitarian assistance to areas that may be hard to reach, and is emphatic, for instance in telehealth initiatives. However, there are also negative impacts that need to be given significant consideration and addressed. Evidently, the intersection between these issues and internal displacement is yet to emerge more concretely in the literature. However, the evolving use of technology and the evolution of artificial intelligence cast against the future of warfare and violence, if current trends are not reversed, makes attention to this root cause an imperative in strengthening legal protection and addressing internal displacement in Africa. Understanding technology in the IDP context opens up a dimension of debate and discourse on this intersection and on how proactively to regulate the use of technology to prevent situations of internal displacement. For instance, unmanned aerial vehicles are gaining interest in modern warfare. ${ }^{58}$ There is an evident potential that future forms of warfare will be a mix of human and non-human efforts. Proactively articulating protection on issues that are likely to become prevalent concerns is integral to the protection and assistance of IDPs.

\section{CONCLUSION}

Over the last decade, the influence of the UNGP has resonated significantly in various contexts. However, nowhere else is the normative value of the UNGP more expressive than in Africa, with the exposition of norms at national and regional levels. Indeed, the UNGP have shaped political orientations and have become a valuable springboard from which various norms have found expression. Although this is duly acknowledged, the extent of this reflection is yet to gain notable traction in the literature. Moreover, there is another pertinent angle to the conversation for which not much is being stated; these are emerging trends that normative frameworks also need to incorporate in strengthening the law on internal displacement in Africa and, by extension, to the rest of the world. This article has examined areas of synergies and

58 See UN Human Rights Council "Report of the Special Rapporteur on the Promotion and Protection of Human Rights and Fundamental Freedoms While Countering Terrorism, Ben Emmerson", UN doc A/HRC/25/59 (11 March 2014); PL Bergen and J Rowland "World of drones: The global proliferation of drone technology" in PL Bergen and D Rothenberg (eds) Drone Wards: Transforming Conflict, Law, and Policy (2015, Cambridge University Press) 300; I Henderson and P Keane "Air and missile warfare" in R Liivoja and $\mathrm{T}$ McCormack (eds) Routledge Handbook of the Law of Armed Conflict (2016, Routledge) 282; M Schulzke The Morality of Drone Warfare and the Politics of Regulation (2017, Palgrave Macmillan); JI Walsh and M Schulzke Drones and Support for the Use of Force (2018, University of Michigan Press). 
expansions from the global to the African regional context. However, if the UNGP are to continue to find expression, it is imperative that there is sustained political commitment at various levels of governance to the furtherance of the UNGP's provisions through the enactment of laws and policies that reflect their provisions and areas in which the Kampala Convention expands on its normative protection.

\section{CONFLICTS OF INTEREST}

None 